Journal of Social and Development Sciences

Vol. 3, No. 8, pp. 293-303, Aug 2012 (ISSN 2221-1152)

\title{
Structuring Urban Sustainability with Water: A Case of Kamrangir Chor, Dhaka, Bangladesh
}

\author{
Rumana Asad, ${ }^{*}$ Reazul Ahsan \\ Khulna University, Khulna, Bangladesh \\ *rahsan@kuurp.ac.bd
}

\begin{abstract}
Too much or too little water is always a challenge for any water related issue, especially for developing countries where water is abundant or crisis like Bangladesh with the change of circumstances. Dhaka the capital of Bangladesh is facing a serious water scarcity problem due to the big gap between demand and supply of water system. On the other hand it can be say that this water crisis originated due to too much water like floods, rainfall, drought etc. that force rural people from other part of country towards city and city is losing its hydrological balance to accommodate these unwanted migrated people. Dhaka has experiencing a tremendous pressure and transformation in terms of its water system due to such unmanageable urban growth and uncontrolled urbanization. Design strategies and solution are needed to respond for pressing climate and environmental changes and necessary to take action against the ubiquitous human mismanagement of the essential resource of water. To overcome these water related problem water can be a designing element for structuring future development with the combination of sustainable approaches for social and physical transformation, open up opportunities for land water management system. This paper will try to find the changing relation between the city and its water system. Using Kamrangir chor a water linked suburb in Dhaka as an experimental site this paper will also frame some urban design strategies for reducing water damages, revitalize water sources, productive water parks, which will structure new water based urban development.
\end{abstract}

Keywords: Water, urbanization, urban sustainability, environment, design strategies.

\section{Introduction}

Planning with water is one of the great contemporary challenges concerning urban-environmental management. The distribution, allocation and management of water resource remain a major concern in development thoughts and practices for decades. Particularly, in many water stressed regions of the world, it plays a central role in social, economic and political processes (Kobori and Glantz, 1998 in Arsel \& Spoor, 2010). Bangladesh was known as a "Land of water" or better still "water in land" (Novak 1993). The country is situated on the world's largest delta- within the catchment area of the Ganges, Brahmaputra and Meghna rivers, which mainly drain through Bangladesh into the Bay of Bengal. Most of the parts are disadvantaged, over- populated and inefficiently governed nation are less than twelve meters above sea level and it is estimated that approximately 50 percent of the land area would be flooded if the sea level were to rise by a meter (Shannon \& Nilufar, 2008). Bangladesh has known as highly vulnerable position in world context due to climate change impacts and sea-level rise thus sway many natural disasters and flooding almost every year. Like many other cities in the world, Dhaka the capital of Bangladesh, was developed base on its rivers and water system. Largely, the city had shaped by the way of water bounded by Balu River on the east, Turag River on the west, the Buriganga River on the west and south and the Tongi Khal on the north. The city had its internal system of canals, ponds, lakes and water reservoirs, which spread as webs throughout the topography and worked as major natural drainage system. From $1 \mathrm{~km}^{2}$ area at 1600 (Islam 1974 in Huq \& Alam, 2003) Dhaka ranked 11 $11^{\text {th }}$ among world's largest megacity in 2000 and is stated as the sixth most populous city in 2010 and would be the second largest megacity in 2015(Islam, 2005) with an area of 1,528 $\mathrm{km}^{2}$. Over the last four hundred years of urban development, Dhaka has completely lost its image of 'Venice of the East or the City of Channels' as remarked by James Taylor (Dani, 1962) and presently stands as 'City of concrete'. Physical planning respecting city's internal canals, ponds, lakes and reservoirs that once served as a natural drainage and also transport corridors for city dwellers, never been created to guide the expansion of the city that result a serious pressure on its water resource. 
Rather than managing, the rapid growth the city is being recklessly urbanized encroaching most of the lowlying areas and water channels, which had previously served as necessary sponges for Dhaka. About 18.72 $\mathrm{km} 2$ of Rivers \& Khals and about $76.67 \mathrm{~km} 2$ of wetland are lost during last 30 years from 1978 to 2009 (Mahmud et al 2011). Various studies have insist on Water resource management should arguably be at the core of the city's planning and development (Shanon, 2008, Peeters, 2011) and more and more retention areas are needed to protect the city from water logging which is identified as one of the major problems of the city (World Bank 2007). But in reality, the city is facing an enormous challenge for resolving much diverse water related issues like pollution, ever -expanding needs of water supply with demands, floods, declination of water transportation system and water logging due to wide spread illegal encroachment, land filling and severe environmental degradation of water bodies. Kamrangir chor is one of the newly developed urbanized area of Dhaka city that occupy an area of $3.68 \mathrm{sq}$. km with population of 0.26 million in 2010 and projected population would be .37 million by 2015 (RAJUK, 2010). Demand of low-income housing near the city core accelerates the population density of this area, which terminates towards informal settlement. It is mainly a low-income area that sits between two different types of development encircling by river Buriganga and its tributaries. One side is junk of concrete structures with limited green and blue spots of old Dhaka from where the city started and other side is soft texture of green and blue containing spontaneous settlement of village dwellers with agricultural land and small canals. The potential to create places, boundaries, transitions and accesses in such sites has yet to be properly explored. The ambiguity of these spaces calls for a design approach that reconsiders discontinuities and voids an opportunities to restructure the urban fabric (Langenbach, 2007). The design proposal presented in this paper has shown in a conceptual way, a particular approach to renewal of study area that works basically as a service area in the context of a mega city, Dhaka. The paper begins with a site interpretation, which, at first sight, focuses on changing scenario of waterscape with the demand of urbanization, environmental aspects related to a very specific waterscape, addressing problems of encroachment, drainage, pollution etc. based on available documentation and field survey. Finally, it develops possible design approaches for this precise site area based on an integrated approach to environmental and urban functions of waterside spaces. Considerations towards environmental, economic and socio-cultural dynamics have involved for creating a sustainable living environment not only for its residents but also facilitate the city people.

\section{Literature Review}

Historically, relationship between water and human settlements has very intense "because it was where the people arrived as they came from or because it was the land's outlet to the sea" (Bender, 1993). Greater human civilizations in world have flourished along the rivers, lakes, on estuaries, near deltas and at the sea edges. Formerly, the most important functions of water in a human settlement were to provide drinking water, infrastructure for water transport, basin for the disposal of wastewater and fishing. Klaasen (1993) but with the increasing population growth and the demand of rapid urbanization had cut the relation between settlement and water. Urbanity has generally evolved around reliable sources of water to meet the immediate needs of humans. However, rapid urbanization along water bodies is always accompanied with immense challenges for both the water environments and the communities depending on this important resource (Odai, 2009). The impacts of urbanization on urban water management are complex and occur in various ways and a wide range of scales, affecting the availability and quality of water, as well as altering the natural hydrologic cycle in urban areas (Zandaryaa \& Guibert, 2009). Urbanization is not a single condition (Booth et al., 2004 in Odai, 2009) instead it is a collection of actions that lead to a recognizable landscape forms and, in turn to changes in stream conditions. No single change defines urbanization, but the cumulative effect of human activities in urban basins profoundly influences streams and their biota (Konrad and booth, 2005). Urbanity transcends city physical circumstances, as it includes the "courteous and affable qualities, related to continuous negotiation of interests" (Mello \& Holenda, 2009) identified the relation between the city and water by two basic trends-one consider water an element of urban design and other water as disregarded by use them as dump yard. Their study shows that promoting urbanity beside waterscape is the interpersonal relationships between human and the water sources that not only contribute the quality of life and quality of the urban scape, but also as strategies for the effective protection of the environmental resources. According to Shrestha (2009) water should be used as an anchoring point for a diverse system of public amenities. Water sites require special consideration in land use planning and should be viewed as an opportunity to provide public amenities to meet the needs of urban regions. Urban sustainability regarding 
water issues will derive from achieving feasible and adequate solutions for safe drinking water for all its inhabitants reduce health risk from both pollution sources and flood events, to guarantee adequate water sources to sustain economic activity and to create a pleasant environment. Urban sustainability will also greatly depend on reducing its ecological footprint, by reducing water consumption and consequently reducing externalities such as pollution exportation and flood events (Porto, 2009). For upcoming decades, climate change will be a serious threat that the global society has to face. It will have significant impacts on the availability of water, as well as the quality and quantity of water that is available and accessible. Moreover, that will have important consequences for human populations, through impacts to agriculture and food security, health, economic activity, increasing natural disasters and conflict over water resources. Amongst 11 Asian mega cities Dhaka is ranked as the most vulnerable city to climate change impacts for its lowest adaptive capacity and high population density (Harmeling, 2010). Rising temperature, melting glacier and erratic rainfall increase the frequency of floods. Extreme floods are now coming every 5 years instead of every 20 years. In 2008, 22\% households affected by tidal surge flood and $16 \%$ affected by riverbank erosion moved to urban areas and those displaced and vulnerable communities migrate to urban areas in search of livelihood (Black et al., 2011). Climate change drawing people to cities beside traditional social and economic migration and that also need to be addressed within the institutional framework of urban development (Ahsan et. al, 2011). Water resources must be viewed holistically, considering both their natural state and the need to balance competing demands - domestic, agricultural, industrial and environmental - to ensure sustainability climate change will require a radical shift within design practice from the solid-state view of landscape urbanism to the more dynamic, liquid-state view of waterscape urbanism (UNESCO-WWAP 2009).

\section{Water Evolution in City Context}

Dhaka is predominantly a water-based city. The development history of Dhaka is old and is known to be in existence since the 7th century. The city lies on an alluvial terrace above the northern bank of the Buriganga River, which offers access through the major regional rivers. It is now assume that Buriganga formed the southern boundary and the old town is bounded by the Dulai River - a waterway coming from the north and curving eastward as it joins the Buriganga; which is no longer exists. It is quite likely that, following the course of the Buriganga, settlements grew on the southern, western, and northwestern parts of the city. These, of course, were sporadic growths with the riverbank determining the basis for settlement (Chowdhury \& Faruqi, 1989). According to Islam (2005), selection of Dhaka as the capital of Bengal by the Mughal emperors (1604-1764) was definitely an intelligent one due to surrounded by a ring of rivers, the city was strategically located for protection against enemy attacks. It was also located in the center of a productive agricultural area, while the river also provided good communication to the hinterland. In 1608, the Mughal governor Islam Khan built an artificial canal joining the Dulai to the Buriganga, thus forming a western boundary for the old town. Dhaka was one of the major river ports during second half of $17^{\text {th }}$ century, which make the riverfront more active in terms of trade. Tavernier, who came to Dhaka in 1666 A.D, speaks of Dhaka as a great town, which extended only its length, because everyone desired to have a house by the side of the river. The riverfront worked both both for trade and business as well as recreational space for the historical city. At the initial time of British rule, (1764-1857) water system was very much present in terms of mobility, natural drainage and as ecological space and the riverside Buriganga was the front yard of the city. However, in late colonial period (1858-1947), Dhaka underwent a vast physical renewal following no definite plan. This growth transformed the medieval Dhaka into a modern city with metal led roads, open spaces, streetlights and piped water supply that changed completely the meaning of water (Ahmed 1986). By the 1930, riverfront also lost its desirable residential character and become both a low- class residential area and the city's main commercial center (Huq, 1999). After being the provincial capital of the East Pakistan (19471971), a master plan was developed in 1959 to frame the growth of Dhaka covering an area about $829 \mathrm{~km}^{2}$. Rather than providing solutions to the problems created by rapid growth it mentioned the encroachment of the low-lying areas (2-5 meters) - which had previously served as necessary sponges for Dhaka-are also being recklessly urbanized (Peeter \& Shannon, 2011). Riverfront of old Dhaka became denser and the transport network system is no longer present inside the city. After independence in 1971, being the capital of newly independent country, Bangladesh, the urbanization process of the city has achieved tremendous growth with fast increasing population of rural migrants and structural development. Keeping pace with the magnitude of the urban growth, the new urbanized areas began encroaching on the low-lying areas within the city limits and even on some adjacent outlying areas (Siddiqui et al., 2000). Originally, there were 43 canals 
in the city that worked as major drainage system and transportation corridor into the city; but now restoration plans for only17 have been proposed.

Islam, (2005) Eight of the disappeared canals has been replaced by box culverts-a hollow concrete box section under the ground-and consequently covered by important roads. Other canals exist but are rarely seen, because of the encroachment and filling-in either by developers, squatters or the government itself (Alam \& Rabbani, 2007, p. 95). Dhaka City has faced its highest rate of physical and population growth during 1981-1990.The population increase from 3.4 million to 6.8 million (Islam 2005) and city expanded from 510 sq. km to 1353 sq. km. (Siddiqui et al., 2000). By 1990s, many of the khals in the Old City were converted into underground drainage and sewerage box culverts; hidden underneath a number of the city's main highways. In a way, people preferred roads instead of the smelly khals because it reduced flooding around the former khal and it was a solution for the traffic congestion (Khatun, 2009 in Peteer 2011). To meet the rapid urbanization process the city mostly guided by land based development rather than cope inherent water system as an element for further development. The river Buriganga, however is still a busy waterway, less for inter urban movement but more for regional connection with the city (Islam, 2001). It works as the main terminal for city transportation with southern part of the country and base point for transferring goods. It also accommodates many types of economic livelihood and the cultural identity of local dwellers. River from untreated sewage and chemical waste discharges from a number of industries, including tanneries in the west transform the riverbed as a backyard for the city dwellers. It is noticeable that only northern side of river Buriganga was urbanized and expanded to the north following available higher contours and railway line until 1990 and there was no physical expansion to the southern boundary of river Buriganga. However, after the construction of bridges over Buriganga and enormous migration pressure towards city encouraged this expansion to south, mostly on low-lying areas, even lands in between 1-3 meters above mean sea level that makes most parts vulnerable. The city is expanding without any planning guidelines and minimum sensitivity for either law or environmental sustainability that transformed the water as nothing more than a burden for its dwellers.

\section{Water Scape of Kamrangir Chor}

Region's largest threat and assets river Buriganga has enclosed more than two third peripheral area of Kamrangir chor in such a way that it seems the Buriganganga keeps the area into its womb. Kamrangir chor is separated from the city by one of the braches of Buriganga that once called 'Buriganga Joti Nadi'; now transformed into a narrow canal of polluted slime. The river was played a significant role to reach 'Lalbagh Fort', which was the center of power at Mughal time period. Kamrangir chor has conserved its rural image until 90's, but after the construction of western embankment under FAP (Flood Protection Plan) to mitigate flood damages for greater Dhaka, the area suddenly boost out with higher density. Migrated people from city surroundings has encroached all the flood flow areas that was served as agricultural land of village dwellers. Commercial, residential, industrial land uses make their own way haphazardly without any planning and maintaining minimum rules and regulating for flood protection. Easy accessibility to city core, low land price, employment followed by attraction of urban facilities etc. is some main reasons for sudden change of rural fabric to urban. The areas beside the river 'Joti' has mentioned as water retention pond for Dhaka city in DMDP (Dhaka Metropolitan Development Plan). The land use for such water retention areas have restricted with agriculture, fish cultivation and recreation only; any land filling and construction of permanent structures are totally forbidden. However, in reality, already permanent and semi-permanent structures have forced the existing narrow canal to fill and be a part of land around western embankment. In DMDP it indicated that policy will be implement through land use control that will further detail in DAP (Detail Area Plan) through planning process. However, unfortunately due to political pressure against land acquire and ignorance of related representatives; no clear guidelines can found. Lowlands with $1 \mathrm{~m}$ high on northwestern part of study area are indicated as flood flow zone at DMDP and strictly forbidden any kind of construction works and land filling. Site observation findings state that approximately one-third part of this zone has by now filled up by a well-known private medical college and hospital. In addition, remaining land areas have already under power of private developers and proposed for future housing. In proposed area development by DAP all of such illegal encroachments have accepted and the most interesting part of this plan is that the area which has demarked as playground for future communities keep under water throughout the year in reality. To pursue the planning further land filling will be required. From field survey 
observations it seems that due to unawareness of government authorities creating scopes for greedy land grabbers for further encroachment and very soon the area will be totally transform to concrete slabs without leaving a single space for water.

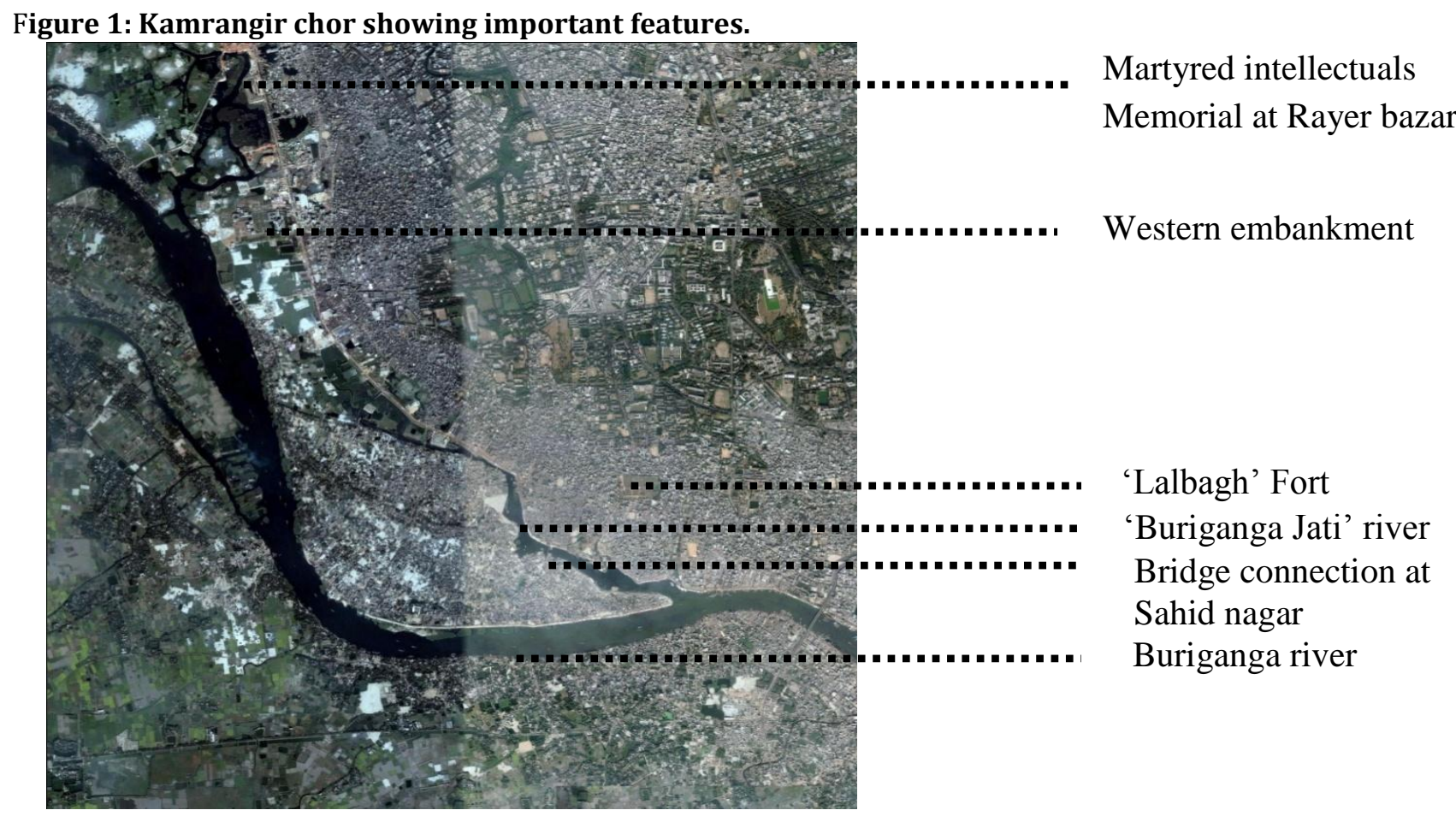

Source: Google-map

Pollution and Encroachment Issues: Almagir (2007) mentioned urbanization and Environmental degradation go side-by side to support uncontrolled development and to meet growing urban demand. The physical environment of the study area is very poor. The area basically developed as service zone to facilitate the commercial activities of old Dhaka along the northern periphery of Buriganga River. Mostly slum and squatter settlements with small industries have observed throughout the study area. Generally, illiterate migrants from rural areas who are unaware about environmental issues have come to accommodate their basic needs only. Rather thinking water bodies as an important part of natural drainage system and its strength of being a breathing space for whole community, they take waterway as vessels for liquid and solid waste. Unavailability of municipal services for waste collection also influence them to dump their household wastes on mainly wet lands, open spaces and river bank to fill up the water bodies and low lands (Figure 2). About $85 \%$ of the households are responsible for such activities (RAJUK, 2010).

\section{Figure 2: Views of water pollution}

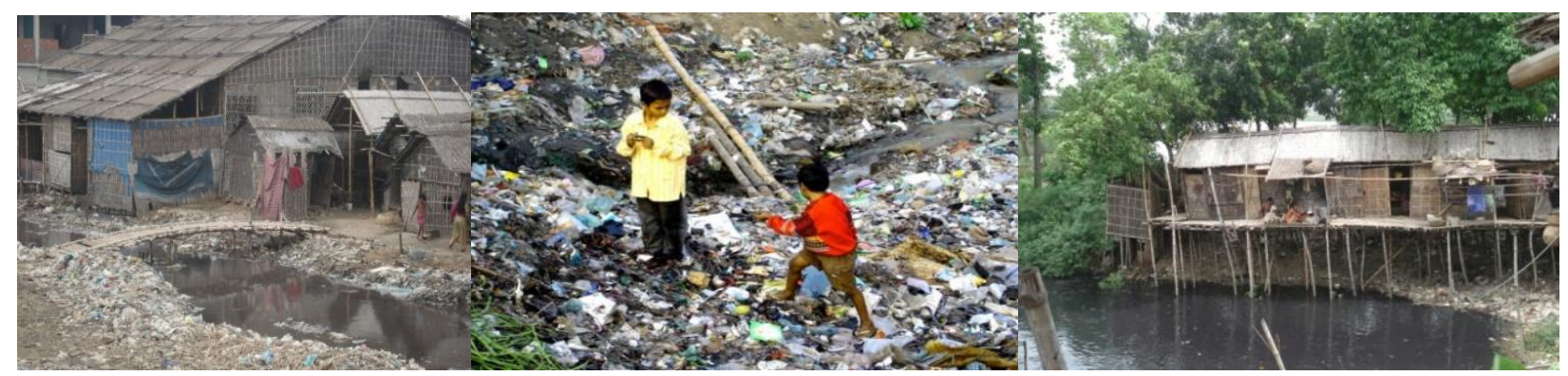

Source: Photographs taken by authors 2009. 
The most alarming thing is there are many small scale plastic and leather industries have developed in this area that never been follow any legal procedures. Burning leather and plastic on open air and throwing out the wastage on nearby water sources and low lands is a common scenario all over the study area. Continuous waste dumping on nearby water source, low lands and open spaces not only produce degraded physical environment but also create new lands through waste filling which make the way for further encroachment. Moves to evict the illegal encroachments have so far failed to make any progress as that often backed by the local bigwigs who are reportedly busy to consolidate their gains through reclaiming land, the most precious thing in and around the capital city from the riverbed.

A large part of Buriganga riverbank round Kamrangir chor has covered by temporary structures on stilts and hanging latrines that play as important sources of water pollution (Figure 3). Four to six storied permanent illegal structures stands facing back towards water way. Unauthorized structures have squeezed the width and obstruct the natural flow of water regimes. Domestic wastes as well as polluted industrial water with unhygienic chemicals from the industries disrupt the total hydraulic system by turning water into black, stinging and unusable. Rather than being amenity for local community as well as city people the water bodies around Kamrangir chor work as waste disposal zone for local dwellers. By analyzing the relationship between the existing water lines and the urban settings, it can be concluded that an overwhelm nature of urbanization has viewed towards water system that create a dysfunctional relationship between hydrology and such water system.

Figure 3: Issues of Encroachment

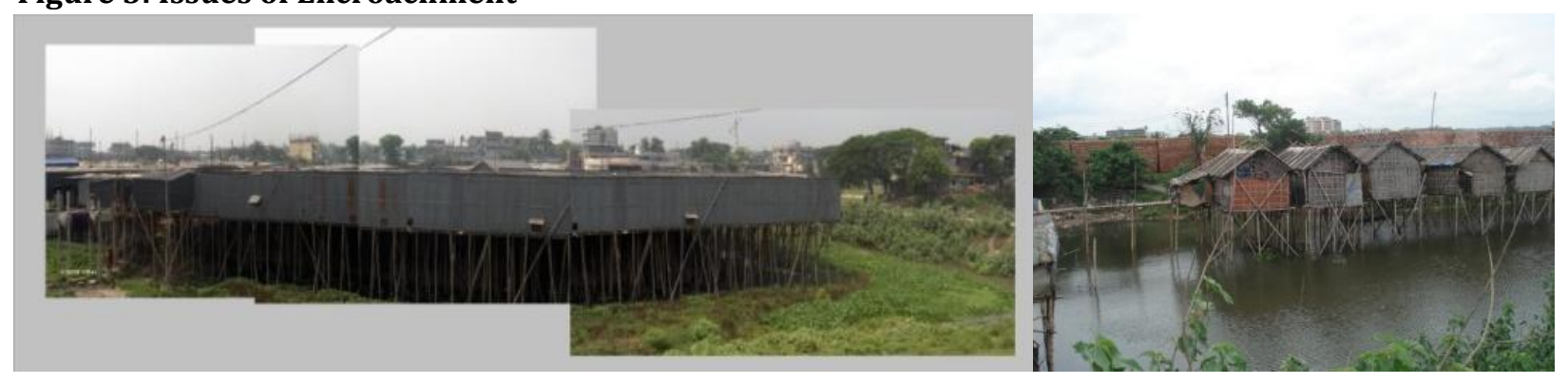

Source: Photographs taken by authors 2009

\section{Water as Structuring Urban Sustainability}

No doubt, that water plays the most significant role for the establishment, urbanization and physical growth of Kamrangir chor. It creates employment opportunities (fishing, boating, irrigation etc.), give transportation facilities (can access any points by boat), recreation (bathing, gossiping, playing at riverbank) as well as ensure cultural identity of local dwellers. On the contrary most of the water retention areas have already occupied that destroy the flood resilience capacity which generate floods followed by water logging problems during rainy season. In addition, the intoxication levels of these water sources are so high that it enhances the fair of many water borne diseases. In this contradictory movements of water regime, Kamrangir chor has chosen as research area where water itself use as structuring element to enrich the physical environment by creating relation between infrastructure, landscape and settlements. In this sense, the research attempts to answer the need of the inhabitants to enjoy the water, which has a constant present along the study area by the structuring of housing, urban agriculture, green corridor and productive park. The proposed water structure includes several water systems: build water infrastructure negotiating road based communication service, rainwater collector zone along low lands, water filtration system to serve an urban agriculture irrigation system, ground water recharge and water retention pond. Re addressing encroached land with acquiring land of riverbank, spaces combined with a system of retention pond and park has designed to allow city people in an area of culture and leisure. This riverfront development produces an unexpected point of contact of people and water, at the city periphery, which can be work as heart of overcrowded spaces of site surroundings. Internal road network has developed by extending some major roads and traffic problems has solved by separating different types of vehicle and pedestrian loop at entry and exit point over water. Connect the existing roads along river with proposed new roads along water, thus people can enjoy the river view 
when travelling and access any point of site periphery. Throughout the development of the project concept and proposal, technical and deign questions emerged. Addressing the actual condition of water it may seem not is viable solution due to uncontrolled formal use of Buriganga River by city people. However, it can be made possible by introducing artificial engineering maneuvers and water chemical treatment plant for water purification. Therefore, the principle to associate different technical and design solutions is to achieve the possible viable practical solutions. These local scale solutions can be only possible within a wider framework, where the entire water shed is viewed in a water management perspective at a regional scale. The following design strategies reveal how small and medium scale efforts can the sustainable forms of urbanism.

Structuring Water infrastructure: The city cannot survive without capturing, transforming and transporting nature's water. The metabolism of the city depends on the incessant flow of water through its veins (Swyngedouw, 1996). Through analysis of available maps and historical records it seems that once Kamrangir chor was totally separated from Dhaka city by river Jati and through water way the site was connected with city and its surroundings. Now, the water body of southwestern and southeastern periphery still serves as transportation line. After construction of still bridge over the canal near Sahidnagar and two bridges near Nawabgong and also other informal entry, points transformed the mode of communication for northern periphery. Along the western embankment study area still contains some water dots which possibly the previous water route (Figure 4-A). This water source is continuously losing by uncontrolled encroachment, continuous land filling and huge amount of pollution. Controlling the flow of water implies controlling the city, as without the uninterrupted flowing of water, the city's metabolism would come to a halt. (Swyngedouw, 2004:2). The research has proposed of new intervention of artificial canals by connecting existing water dots that will re-established the transportation route, as well as increase the drainage capacity of the site itself (Figure 4-B). With the intention of restore the navigability of water ways around Dhaka, reducing traffic jam within the city, save environment, enhance fisheries and agricultural land and over all promoting tourism BIWTA (Bangladesh Inland Water Transport Authority) has proposed Circular water way project by connecting major rivers and canals surrounding the city. With new connected water corridors along with previous water route, the site will be more accessible for the city people after completion of this project. Integrated with present road based communication (with basic moderation) water can work as major infrastructure to reduce the pressure on transportation demand and also mitigate the present traffics that the site is facing (Figure 4-C). This proposed connected water way not only increase the water quality and reduce water stagnancy, but also be a productive space for holding the existing 'bede' (people who lives in boats on river) communities who is disappearing day by day.

\section{Figure 4: Chronological development approach of structuring possible water infrastructure.}
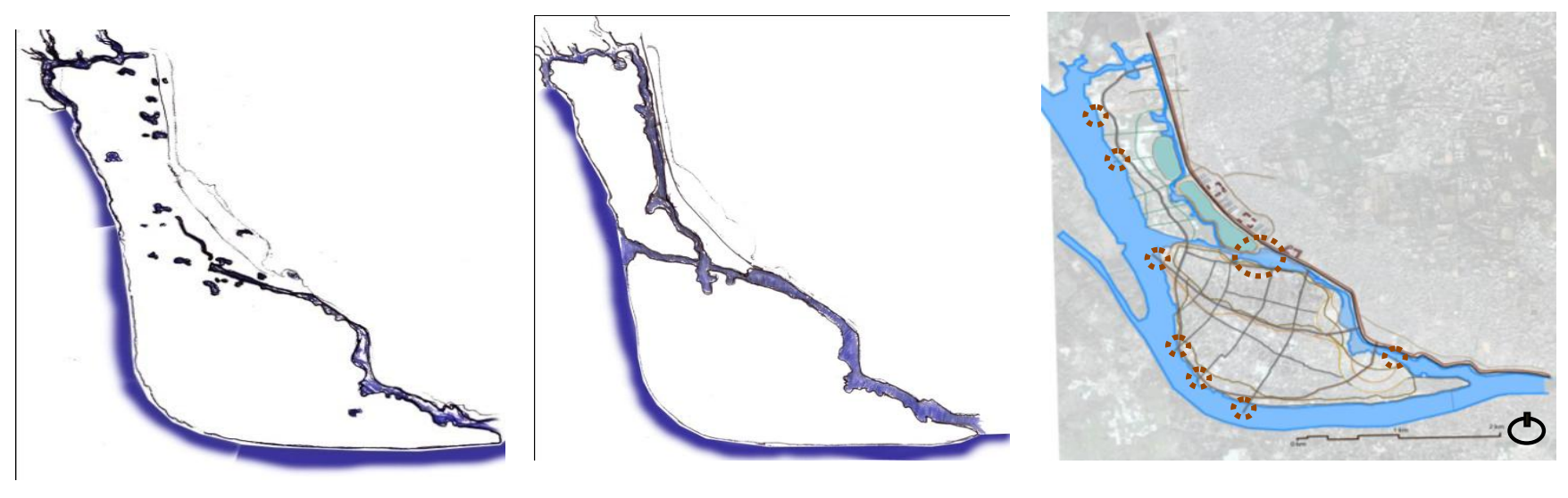

(A) Existing dis - connected water dots of site B)Possible excavation of water route by connecting (C)Proposed design for water infrastructure the water dots.

Source: Obtained and modified by authors. 
Structuring Waterfront: Waterside spaces perform multiple urban functions, structuring cities' development along history. At the same time, these zones are the most dynamic and sensible ones of the water basin, playing essential environmental functions (Mello \& Holenda, 2009). The urban waterfront and its relation to the city have undergone through various cycles of structural change: front door, isolation from the city, deterioration and neglect and redevelopment. (Shrestha, 2009). Waterfront of Buriganga River has already passed through these first three phases and waiting for future development to reconnect with the city. The previous relation between the river 'Jati' and 'Lal bagh fort' is now totally disconnected due to unplanned chaotic development in between. The other side of this canal along study area is also facing tremendous pressure of rapid urban growth and disconnects its inhabitants with water. Roads and settlement come towards water on such a way that it seems these illegal encroachments will capture all the remaining water and be a part of the city very soon (Figure 5-A). This waterfront needs to develop as more dynamic and responsive urban space to regain the water retention area and stop further encroachments. On the other hand, most of the historical buildings and monuments of Dhaka city has developed along the river Buriganga. Although unstructured congested development of 'Old city' destroy the relation between river and these build forms, but still they work as major touristic spots for Dhaka city. These historical monuments allows the water front adjacent shaid nagar to develop as an area of culture, leisure, combined with a system of water retention ponds and urban void. Respecting existing road lines as major vehicular access roads towards site; new roads as bicycle tracks, pedestrian lane as well as green open spaces have proposed to create an environment friendly productive urban void for the city (Figure 4-B). With the motivation of ensuring sustainable living environment, this research has proposed to remove all illegal encroachments beside riverbank and reinforce the water retention area, which have mentioned in DMDP (Figure 4-C). Developing clean clear waterfront with recreational spaces instead of black narrow canal will give the city a breathing space, which the city is suffering for many years. It can be also a great touristic hub, as it already linked some importation heritage structures of old Dhaka. Proposed new river-front development connected with proposed Boulevard along western embankment and well-developed water infrastructure can also help to increase the economy by raising public activities and enhancing touristic business.

Figure 5: Chronological development approach of structuring possible riverfront.

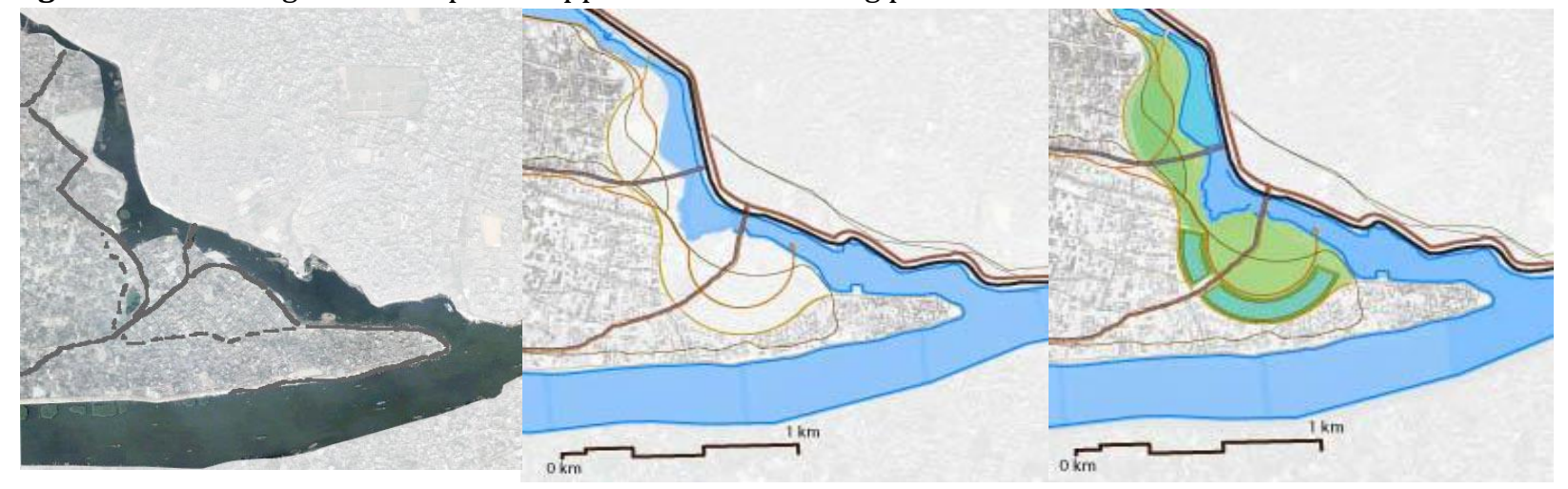

(A)Existing river front in terms of road and water system
(B) Proposed road system in front of river bank
(C) Proposed riverfront incorporating with road, water and DMDP proposal.

Source: Obtained and modified by authors

Structuring too much \& Too little Water: Too much Water is a cleansing and life bringing force; yet it is equally a threatening force because of its disaster effects (Feyen et al, 2009). Too little water- both plays an important role for human settlement in the world. In one, hand too much water like floods, drought, and erosion etc. force rural people to migrate towards urban area that increase urban population and force for further expansion. On the other hand city fail to adopt proper physical planning with this rapid urbanization and loses natural water bodies, open spaces, natural drainage system that induce further environmental hazards for urban dwellers. Contain, drain as well as conserve -above all structure the water system should be the major concern for any physical development of city planning that can ensure the urban sustainability for future. Considering the study area as a part of city this research has proposed some following guidelines to structure the water system. 
Ground water recharge: Kamrangir chor which is facing a dangerous water scarcity due to lack of water supply system will also a big threat for Dhaka city for upcoming ground water depletion, as the site is fully depend on hand tube wall water supply system which reducing the level of ground water. To overcome this situation and be a part of increasing ground water systems for Dhaka city this design interventions are focusing on increase the green and water bodies of the study area. A rainwater storage zone has proposed on the flood flow zone to increase the water surfaces and protecting it is for upcoming encroachment of surroundings.

Flood Control: Water is progressively accepted as an element that shapes landscape and floods as part of the morphogenetic processes (Langenbach, 2007). Several studies on different context prescribe to live with flood rather to control, that means give the spaces to be flooded around flood source. A large green field beside the riverbank by connecting existing green spaces with open space after removing illegal settlement from bank could be a productive approach for controlling flood. This place will be flooded during wet season and for dry season; it will work as recreational space with street shopping, loading, unloading zone of goods, community interaction space, that production \& ecology. A new settlement on stilt has proposed to allow without destroying the agricultural activities. Reestablished of flood flow zones with agricultural land and the water reservoir tank will create a new land-water- man relationship within the site.

\section{Figure 6: Flood control management through natural process}

(A) 'Kamrangir chor' in dry season

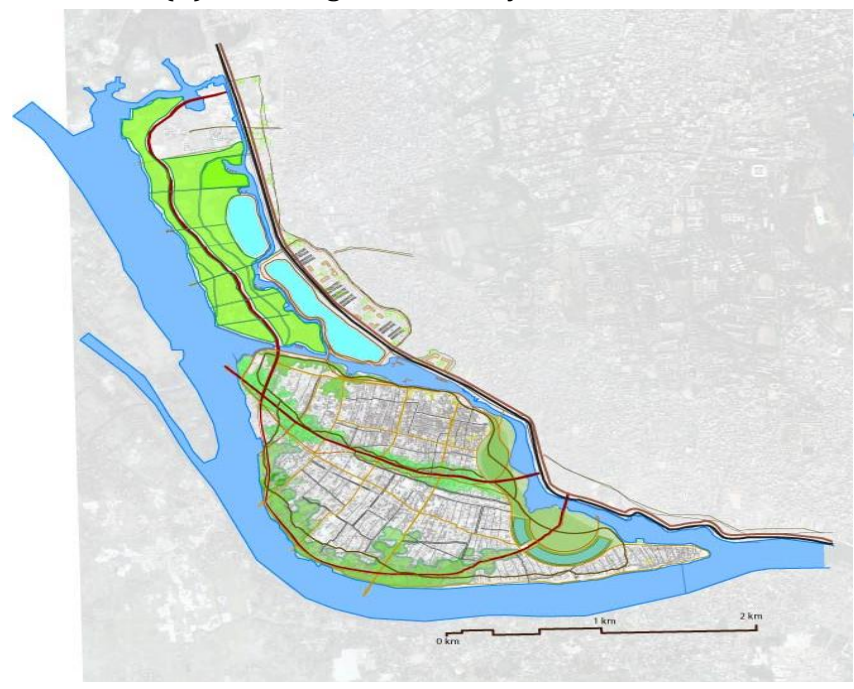

(B) 'Kamrangir chor' in wet season

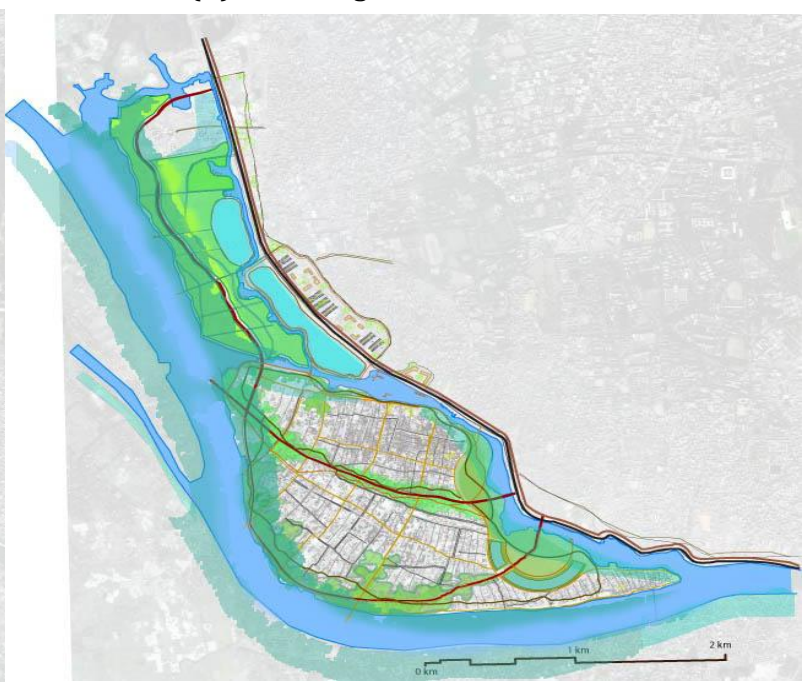

Source: Obtained and modified by authors.

Rainwater harvesting: Rain water harvesting is a good way of collecting waters from nature and uses it in agricultural field and daily domestic use, which is an easy way to solve the future water scarcity problems of the site. New Building typologies has proposed for the site for the future development for smart way of collecting rain water and use it in domestic purpose. Lowland area behind the new development would act as a recreational space at the city scale as well as a reservoir for water during the flooding season. A rainwater collector has proposed at low lands area, which may reserve water for dry season in, wet season. After treatment, this water can be used in agricultural field. The water collected could then partially be rooted to a filtering system that would allow it to be used for irrigation on nearby agricultural land.

\section{Conclusion}

If we plot the relation between Urbanity and hydrology then we found that water played the most important role for the creation of cities and spreading urbanity throughout the world. Today, the cities are growing so fast that the fragile equilibrium relation between urbanization and water system is under pressure. Left behind the harmonious relation with water system cities are incredibly more facing more floods, pollutions, 
disparity between water demand and supply- associated with water related problems. To get rid from this situation, rediscovering water as an element of urban development and composition has started to practice in some developed countries of the world; from nineties. However, for most of the developing countries in the world water still remain as collector of all type of pollutants of urban dwellers rather using its strength of creating a sustainable urban future. Anchoring the most significant landscape element, water with urban design is a very new concept that Asian cities have started to practice. Countries like Bangladesh where most of the lands formed by thriving of thousands of water channels and the age of rapid urbanization is not more than half century, there water system should the backbone for structuring urbanity. Taking 'Water' as an urban issue this research has tried to develop some strategic proposals for future development considering present situations and all the alternatives that may reflect the past and shape a new dream as it possess these potentialities. Here, water attempts to contribute the shift of perception of functional and ecological systems. It will show how changes in use and multiple uses can allow natural systems to work when implemented and integrated within the urban tissue. Disregarding indigenous methods of urban design and planning and implementing master planning and static land use planning without respecting its landscape elements have already proved as insufficient to deal with the complexities and uncertainties of contemporary urbanism. Water must be introduced and reintegrated into urban landscape rater think it as a separate problem to solve. Water urbanism is possible when urban planning and design, civil and sanitary engineering and landscape architecture are folded into one another as are concerns for mobility, health, recreation and scenery (Shannon, 2009). Our research of ensuring urban sustainability with water, especially focus on Kamrangir chor, Dhaka, will obviously not overall solution for all water related problems thus the city is currently facing. But just as a reply of various pressures such as socio-economic development, on-going urbanization in flood prone land, and climate change, water is indeed to converted into a stronger strategic instrument, where planners aim to stimulate the search for identifying interesting chances for multiple land use, attractiveness and innovative solutions, or even highlighting the role of water identity- building, quality of life, and attractiveness (AL, 2004 in Woltjer, 2009).

\section{References}

Ahsan, R., Kellett, J. \& Karuppannan, S. (2011). A theoretical framework for analyzing climate impact. Paper presented at the World Planning Schools Congress, Perth, Western Australia.

Ahmed, S. U. (1986). Dacca: A Study in Urban History and Development. London: Curzon Press Ltd

Alam, M. \& Rabbani, M. G. (2007). Vulnerabilities and Responses to Climate Change for Dhaka. Environment and Urbanization, 19, 81-97.

Alamgir, F. \& Watanabe, S. (2007). NGO Savings and CREDIT Scheme: Effectiveness in improving the quality of life of the urban poor in different Poverty levels in Dhaka. In: Jahan \& Moniruzzaman (Eds), Urbanization in Bangladesh, (105-120), Bangladesh Institute of Planners, Bangladesh.

Arsel, M. \& Spoor, M. (2010). Water, Environmental Security and Sustainable Rural Development: Conflict and Cooperation in Central Eurasia, 5. Abingdon [etc.]: Routledge.

Bender, R. (1993). Where the city meets the Shore, In: Bruttomesso, R. (eds). Cities on water, (32-35), Waterfronts, Venice.

Black, R. R. G., Bennett, S., Thomas, S. M. \& Beddington, J. R. (2011). Migration as adaptation. Nature, 478, 447449.

Chowdhury, A. M. \& Faruqui, S. (1989). Physical Growth of Dhaka city. In: Ahmed, S.U. (eds), Dhaka Past, Present, Future, Dhaka Asiatic Society of Bangladesh, Dhaka.

Dani, A, H. (1962). Dacca, A Record of Its Changing Fortunes, Reader in History, University of Dacca and Curator Dacca Museum, Dacca Museum Quarter, Dacca.

DMDP (Dhaka Metropolitan Development Plan). (1997). Dhaka Structure Plan (1995-2015) 1 \& 2, Dhaka.

Feyen, J., Shannon, K. \& Neville, M. (2009). Water \& Urban Development Paradigms-Towards an integration of engineering, design and management approaches, Taylor and Francis Group, London, XII-XV.

Harmeling, S. (2012). Global Climate Risk Index 2012: Who suffers most from extreme weather events? Weather-related loss events in 2010 and 1991 to 2010, Haus, W. S., German watch: Bonn.

Huq, S. (1999). Environmental hazards in Dhaka, In: Mitchel, J. K. (eds.), Crucibles of Hazard: Mega cities and disaster in transition, The United Nations University Press, New York, 119-137.

Huq, S. \& Alam, M. (2003). Flood Management and Vulnerability of Dhaka City, In: Kreimer, M.A. and Carlin, A. (eds), Building Safer Cities: the Future of Disaster Risk, (121-136), Washington D.C., The World Bank. 
Islam, N. (2001). Urbanization Urban Planning and Development and Urban Governance. Centre for Urban Studies, Dhaka.

Islam, N. (2005). Dhaka Now- Contemporary Urban Development, Bangladesh geographical Society, Dhaka, Bangladesh.

Klaasen, L. H. (1993). Some Economic and Geographical Reflections, In: Bruttomesso, R. (eds), Cities on water, (32-35), Waterfronts, Venice.

Konrad, C. P. \& Booth, D. B. (2005). Hydrologic changes in urban streams and their ecological significance. American Fisheries Society Symposium, 47, 157-177.

Langenbach, H. (2007). Flood management: Designing the Risks. Topos-The International Review of Landscape Architecture and Urban design, 60, 77-82.

Mahmud, M. S., Masrur, A., Ishtiaque, A., Haider, F. \& Habiba, U. (2011). Remote Sensing \& GIS Based SpatioTemporal Change Analysis of Wetland in Dhaka City, Bangladesh. Journal of Water Resource and Protection, 3, 781-787.

Mello, S. \& Holenda, F. (2009). There is a City on the Riverside, Proceedings of the 7th International Space Syntax Symposium, ref: 075, Edited by Daniel Koch, Lars Marcus and Jesper Steen, Stockholm: KTH, 2009.

Novak, J. J. (1993). Bangladesh: Reflections on the Water, Indiana, Indiana University Press.

Odai, S. N. (2009). Preserving the hydrology of Urban Ghana through implementing integrated water resources management. In: Feyen, J., Shannon, K. \& Neville, M. (eds.) Water \& Urban Development Paradigms-Towards an integration of engineering, design and management approaches, (45-52), Heverlee, Belgium: CRC Press.

Peeters, S. \& Shannon, K. (2011). Readdressing Dhaka's Public Water Bodies: A Design Research. NakharaJournal of Environmental Design and Planning, 7, 24-46.

Porto, M. F. A. (2009). Rethinking water governances: Towards a new multi dimentional approach for mega cities in developing countries. In: Feyen, J., Shannon, K. \& Neville, M. (eds.) Water \& Urban Development Paradigms-Towards an integration of engineering, design and management approaches; 15-19 September 2008, Heverlee, Belgium: CRC Press, 543-553.

RAJUK. (2010). Preparation of Detail Area Plan for Kamrangir Char Area, Rajdhani Unnayan Kartripakkha (RAJUK): Dhaka.

Shannon, K. (2009). Water urbanism: Hydrological Infrastructure as an urban frame in Vietnam, In: Feyen, J., Shannon, K. \& Neville, M. (eds.) Water \& Urban Development Paradigms-Towards an integration of engineering, design and management approaches, (55-65) Heverlee, Belgium: CRC Press.

Shannon, K. \& Nilufar, F. (2008).Transforming Urban Landscapes. Topos - The International Review of Landscape Architecture and Urban design, 2, 77- 81.

Shrestha, B. K. \& Shrestha, S. (2009). Urban waterfront development patterns: Water as structuring element for urbanity, In: Feyen, J., Shannon, K. \& Neville, M. (eds.) Water \& Urban Development ParadigmsTowards an integration of engineering, design and management approaches,(105-113) Heverlee, Belgium: CRC Press.

Siddiqui, K, Ahmed, J., Awal, A. \& Ahmed, M. (2000). Overcoming the Governance Crisis in Dhaka City. University Press Limited, Dhaka.

Swyngedouw, E. (1996). The City as a Hybrid: On Nature, Society and Cyborg Urbanization. CNS 7(2).

Swyngedouw, E. (2004). Social Power and the Urbanization of Water, New York, Oxford University Press Inc.

UNESCO-WWAP. (2009). Climate Change and Water, An overview from the World Water Development Report 3: Water in a Changing World, United Nations World Water Assessment Program, and Italy.

World Bank. (2007). Dhaka Metropolitan Development Plan Strategic Environmental Assessment, SENES Consult-ants Limited in Association with Techno Consult International Ltd., Dhaka.

Woltjer, J. (2009). How water flows in strategic spatial planning: The strategic role of water in Duch regional planning process. In: Feyen, J., Shannon, K. \& Neville, M. (eds.) Water \& Urban Development Paradigms-Towards an integration of engineering, design and management approaches,(127-136) Heverlee, Belgium: CRC Press.

Zandaryaa, S. \& Guibert, J. A.T. (2009). New directions in urban water management, In: Feyen, J., Shannon, K. \& Neville, M. (eds.) Water \& Urban Development Paradigms-Towards an integration of engineering, design and management approaches (513-518), Heverlee, Belgium: CRC Press. 